УДК 811.111’38:22(045)

\title{
КОНЦЕПТУАЛЬНІ ЕКОТЕМИ В АНГЛОМОВНОМУ БІБЛІЙНОМУ ЕКОДИСКУРСІ
}

\author{
ЖИХАРЕВА О. О.
}

кандидат філологічних наук, доцент

Київський начіональний лінгвістичний університет

eaap@ukr.net

\begin{abstract}
У статті розглянуто ключові дискурсотвірні екоконцепти англомовного біблійного екодискурсу: БОГ, ПРИРОДА, ЛЮДИНА і СОЦІУМ. Специфікація їх взаємозв'язку дозволяє виокремити основні концептуальні екотеми Біблії, які розкривають суть гармонійного існування людини у світі. Концептуальні екотеми визначено за допомогою ïx реконструкції як інтерпретації концептуального змісту біблійних нарацій з опорою на когнітивні операції промінантності, профілювання і суположення траектора й орієнтира (за Р. Ленекером). Смислову структуру біблійних історій, представлену в термінах концептуальних екотем, реконструйовано на основі екологічних субконцептів і концептуальних дескрипторів, які визначаються набором смислових ознак, реалізованих в одиничних контекстах і множинних іноконтекстах біблійних нарацій.
\end{abstract}

Ключові слова: Біблія, біблійний екодискурс, біблійний екоконцепт, біблійна нарація, екоконцепт, концептуальна екотема, смислова ознака.

\section{CONCEPTUAL ECOTOPICS IN ENGLISH BIBLICAL ECODISCOURSE}

ZHYKHARIEVA Olena Oleksandrivna Candidate of Philology, Associate Professor Kyiv National Linguistic University eaap@ukr.net

Introduction. This article examines the key discourse-forming biblical ecoconcepts of GOD, NATURE, HUMAN BEING, and SOCIETY. In their interrelation they constitute conceptual ecotopics of the Bible, which reveal the essence of human harmonious existence in the God's created world. The paper focuses on defining conceptual ecotopics relying upon the notion of reconstrual as an interpretation of biblical narrations' conceptual content by applying R. Langacker's cognitive operations of prominence, profiling, and trajector / landmark alignment.

Purpose. The paper aims at identifying the main conceptual ecotopics of English biblical ecodiscourse.

Methods. The methodology of conceptual analysis that integrates elements of contextual, interpretative, and prototype analyses made it possible to describe each key discourse-forming biblical ecoconcept as a prototypical ground for ecological subconcepts and conceptual ecotopics.

Results. The paper highlights the conceptual ecotopic "God's attitude to man" as a product of the integration involving two key discourse-forming biblical ecoconcepts, those of GOD and HUMAN BEING. In the story about Israelites crossing the Red Sea the integration of these ecoconcepts is realized through the ecological subconcept of PUNISHMENT marked by the conceptual descriptor God's punishment as a manifestation of God's will. The latter is formed by a set of conceptual features actualized in multiple autrecontexts, which represent the conceptual structure of the respective biblical narrations.

Conclusion. The research proves that the main conceptual ecotopics of English biblical ecodiscourse come down to the following: "God's creation of nature", "God's creationof human being (society)", "Man's attitude to nature created by God", "Man's attitude to family and society prescribed by God", "God's attitude to man", "Man's attitude to God".

Key words: Bible, biblical ecodiscourse, biblical ecoconcept, biblical narration, ecoconcept, conceptual ecotopic, conceptual feature. 
Формулювання проблеми та обгрунтування актуальності її розв'язання. Надбання лінгвопоетологічних досліджень концептуального змісту літературних творів, до яких належить і Біблія (Райкен 2002), експлікуються за допомогою певних типів концептів: текстових, художніх, естетичних (Воробйова, 2011, с. 61; Кагановська, 2003, с. 11; Ніконова, 2008, с. 101-102). Погляд на Біблію як дискурс (О.С. Кирилюк, П.В. Мацьків, С.В. Михайлова, О.А. Пороль, Ю.О. Сабадаш, В.Б. Ширшиков) дозволяє виокремити тип концепту, який ми позначаємо як дискурсотвірний біблійний концепт, що розгортається в біблійних текстах, характеризується смисловою різноманітністю і багатоаспектно представлений в текстах Святого Письма. Дискурсотвірні, чи метахтонні концепти “утворюють ім'я дискурсу” та стають “концепт-ідеями відповідного типу дискурсу” (Приходько, 2008, с. 240).

Ураховуючи характер біблійного повістування, у нашому дослідженні вводимо поняття біблійного екоконцепту, який кваліфікуємо як різновид екоконцепту, складне ментальне утворення, що реалізується в біблійному екодискурсі переважно в контексті біблійних нарацій. У зв'язку з цим дискурсотвірний біблійний екоконцепт визначається середовищем функціонування і стійкими асоціативними зв' язками з сукупністю екотем, які розгортаються згідно з певними наративними формулами. Середовищем функціювання, тобто актуалізації та / або конструювання біблійних екоконцептів, $є$ фрагменти завершених за змістом біблійних нарацій, що розкривають суть закладеного Богом гармонійного існування людини у взаємозв'язках з природою та іншими людьми (соціумом). Відповідно, такі фрагменти корелюють з основними концептуальними екотемами, які забезпечують цілісність біблійного наративу, а у своїй сукупності висвітлюють зв'язок між ключовими дискурсотвірними біблійними екоконцептами, необхідність визначення та опису яких становить актуальність цієї статті.

Аналіз останніх досліджень і публікацій. Сучасні дослідники дедалі більше уваги звертають на виявлення способів і засобів концептуалізації дійсності. Предметом вивчення слугують концепти, які описують у термінах фреймової семантики (Жаботинська, 2005; Fillmore, 1968), конструкційної (Goldberg, 1995) та когнітивної граматики (Langacker 2008), концептуальних метафор (Lakoff, Johnson, 1980), мереж концептуальної інтеграції (Fauconnier, Turner, 2002), прототипів (Rosch, 1988), семантичних примітивів (Вежбицкая, 1999) тощо. Метод концептуального аналізу в його заломленні до реконструкції концептів не є однорідним, бо немає єдиного погляду на структуру концепту і набір його компонентів.

Основоположником ідеї концепту вважають середньовічного логіка П. Абеляра, який асоціював концепт з індивідуальною інтерпретацією смислу у прив'язці саме до тексту Біблії і тлумачив концепт як індивідуальну форму “схоплювання" змісту згідно з висловленнями про той чи той предмет. 3 погляду філософії, концепт П. Абеляра є логіко-лінгвістичною категорією (Мартинюк, 2012, с. 38).

У контексті лінгвокультурологічних досліджень (А.П. Бабушкін, С.Г. Воркачов, В.І. Карасик, В.В. Колесов, В.А. Маслова, М.В. Піменова, Г.Г. Слишкін, Ю.С. Степанов) концепт постає як згусток культури у свідомості людини, що входить до ії ментального світу (Степанов, 2004 , с. 43 ), тобто основною ознакою концепту в таких дослідженнях називають культурну інформацію.

3 когнітивних позицій (Н.Ф. Алефіренко, Н.Д. Арутюнова, М.М. Болдирев, С.А. Жаботинська, О.С. Кубрякова, З.Д. Попова, Й.А. Стернін) концепт визначають як одиницю ментального лексикону. У термінах когнітивної семантики концепти не є ізольованими одиницями, а виступають цілісними взаємопов'язаними смисловими утвореннями. Їх розуміння виводиться 3 контексту і потребує фонових знань (Clausner, Croft, 1999, с. 2). Концепти дозволяють “охарактеризувати більш широко різновиди всіх структур мислення. [...] Поведінка людини визначається їі знаннями”, а “знання про зовнішній світ міститься в концептах” (Панасенко, 2010, с. 141). Відповідно, стосунки людей із довкіллям грунтуються на концептуалізації екологічно значущих фрагментів дійсності. Концепти, як і поняття, “упорядковують реальність, 
яку ми сприймаємо, способи нашої поведінки у світі і наші контакти з людьми” (Лакофф, 1990, с. 387). Ми спираємося на визначення концепта як когнітивного явища, когнітивної абстракції, що є “носієм або концентратором певного дискурсу або певної системи знань" (Широков, 2010, с. 100). Це “зерно першосмислу, семантичний зародок слова, діалектична єдність потенційно можливих у явищі образів, значень і смислів словесного знака як вираження невизначеної сутності буття в невизначеній сфері свідомості” (Колесов, 2002, с. 51), що поступово перетворюється на образ, поняття або, як ядро концепту, на символ.

У зв'язку з розглядом концепту з позиції еколінгвістики й екопоетики основною одиницею аналізу в нашому дослідженні визначаємо екоконцепт. У сучасних роботах з еколінгвістики екоконцепт тлумачать як “одиницю ментальних чи психічних ресурсів людської свідомості і тієї інформаційної структури, яка віддзеркалює досвід і знання людини про екологічні реаліі” (Лагутина, 2013, с. 4). Екоконцепт є багатовимірною розумовою одиницею, “що має різні форми мовного вираження, в основі формування якої лежать гетерогенні екосмисли, яка містить емоційно-особистісні, природні й культурні складники" (Пылаева, 2015, с. 93). Саме тому в нашій роботі екоконцепт - це ментальна одиниця, що слугує джерелом смислового розвитку екологічного змісту і втілюється в екообразах, екосимволах або екологічно значущих фрагментах тексту.

Мета статті полягає у визначенні основних концептуальних екотем в англомовному біблійному екодискурсі, що становить об 'єкт нашого дослідження. Для досягнення поставленої мети необхідно розв'язати такі завдання: 1) уточнити поняття “концептуальна екотема" стосовно біблійного екодискурсу; 2) виділити основні концептуальні екотеми англомовної Біблії; 3) розкрити зміст концептуальної екотеми “Ставлення Бога до людини” в проекції на біблійний опис природної катастрофи локального характеру. Предметом нашого дослідження є лінгвальні засоби репрезентації концептуальних екотем в англомовному біблійному екодискурсі.

Виклад основного матеріалу дослідження. Ключовими дискурсотвірними екоконцептами в біблійному екодискурсі виступають БОГ, ПРИРОДА, ЛЮДИНА і СОЦІУМ, що об’єднані в наративній формулі “БОГ створює світ ПРИРОДИ і ЛЮДИНИ (творця СОЦІУМУ) і приписує ЛЮДИНІ дотримуватися законів буття в цьому світі”, що підтверджує їх дискурсотвірний статус.

Специфікація взаємозв'язку зазначених екоконцептів дає змогу визначити основні концептуальні екотеми Біблії. Концептуальна екотема - це поєднання двох (чи трьох) ключових дискурсотвірних біблійних екоконщептів (БОГ - ЛЮДИНА, БОГ - ПРИРОДА, БОГ ЛЮДИНА - СОЦІУМ, БОГ - ЛЮДИНА - ПРИРОДА), що репрезентують певну екотему шляхом їх співвіднесення між собою. Концептуальні екотеми визначають за допомогою ix реконструкції як інтерпретації концептуального змісту їх компонентів за допомогою когнітивних операцій, описаних у когнітивній граматиці Р. Ленекера (2008). До них належать специфікація / схематизація, фокусування, промінантність і перспективізація (там само, с. 55). Як зазначає С.А. Жаботинська (2013), застосування когнітивної операції до будь-якої конщептуальної моделі, що демонструє характер зв'язку між концептами, перетворює іiі на когнітивну модель. У результаті конструювання на основі тієї самої концептуальної моделі можна створити кілька когнітивних моделей (с. 61).

У нашому дослідженні концептуальна модель тієї чи тієї екотеми задається комбінаторикою ключових дискурсотвірних біблійних екоконцептів; при цьому до сформованої концептуальної моделі застосовуються операції промінантності, профілювання та суположення траектора й орієнтира. Промінантність визначається Р. Ленекером (2008) як виокремлення певних елементів (Langacker, 2008, c. 66) на тлі менш виокремлених і експлікованих. Говорячи про профілювання, Р. Ленекер (2008) спирається на поняття концептуальної бази і профілю, важливі для розуміння сутності значення мовного знака. Конщептуальна база - це весь обсяг інформації, що активується концептуальним змістом. Профіль є тією частиною бази, який формує її значення (с. 66). Під час 
профілювання не речі, а відношення, його учасники мають різний ступінь промінантності. Більш промінантний, більш “висвітлений” учасник вважається траектором (trajector), менш промінантний тлумачиться як орієнтир (landmark). Траектор є первинним, а орієнтир вторинним семантичним фокусом (Langacker, 2008, с. 66-67; Жаботинская, 2008, c. 67-68).

Отже, ключові дискурсотвірні біблійні екоконцепти БОГ, ПРИРОДА, ЛЮДИНА і СОЦІУМ профілюються в доменах, які ми називаємо концептуальними екотемами і які складаються з профіля і бази. Так, у концептуальній екотемі “Створення Богом природи" профілюються відношення екоконцептів БОГ - ПРИРОДА, а в концептуальній екотемі “Створення Богом людини (соціуму)” такими є БОГ - ЛЮДИНА - СОЦІУМ. В обох екотемах промінантним $\epsilon$ екоконцепт БОГ (траектор), оскільки на нього спрямований основний фокус уваги. Саме Бог впливає на динамічний розвиток і зміну попереднього устрою, оцінює й описує ситуацію, пов’ язану з появою ПРИРОДИ, ЛЮДИНИ, СОЦІУМУ, які в межах зазначених екотем виступають орієнтирами. В обох випадках "концептуальна база однакова, а профілі різні, що визначає різницю у значенні” (Лэнекер, 2006, с. 19). Оскільки відношення між екоконцептами подано в різних ракурсах, у першій екотемі акцент поставлено на створенні природи, а в другій спочатку на творенні людини, а потім на соціумі.

У концептуальній екотемі “Ставлення людини до природи, створеної Богом” висвітлено відношення екоконцептів у послідовності БОГ - ЛЮДИНА - ПРИРОДА, а в концептуальній екотемі “Приписане Богом ставлення людини до сім'ї і суспільства" це БОГ - ЛЮДИНА СОЦУУМ, де у фокусі уваги перебувають екоконцепти ЛЮДИНА - ПРИРОДА та ЛЮДИНА СОЦІУМ, які, відповідно, виступають траекторами по відношенню до екоконцепта БОГ. Інтерпретації підлягає, по-перше, те, як людина ставиться до природи, створеної Богом; подруге - іiі ставлення до сім'ї і суспільства за законами, заповітами, приписаними Богом.

У концептуальних екотемах "Ставлення Бога до людини” і “Ставлення людини до Бога" профілюються два екоконцепти - БОГ і ЛЮДИНА. Акцентований учасник ситуації набуває статусу траектора, а інший виступає орієнтиром. Отже, залежно від контексту змінюється профілюючий біблійний екоконцепт i, відповідно, формат концептуальної екотеми.

Розглянемо докладніше концептуальну екотему “Ставлення Бога до людини” на прикладі опису природної катастрофи в біблійній історії про перехід народу Ізраїлю через Червоне море, де актуалізовано екологічний субконцепт ПОКАРАННЯ. Зазначена концептуальна екотема стосується настанов Бога людині щодо правил ії життя, що реалізується головно через випробування. У термінах когнітивної граматики траектором у сформульованій екотемі є БОГ, що наставляє людину на правильний шлях, а орієнтиром - ЛЮДИНА, яка підкоряється Господу.

Екологічний субконцепт ПОКАРАННЯ не завжди експлікований у біблійних історіях, але під час аналізу може бути виявлений завдяки відповідним смисловим ознакам. Покарання $\epsilon$ наслідком негативного вчинку, у біблійному екодискурсі характер покарання $є$ також засобом для виправлення чи навернення до віри в Бога. Катастрофи $є$ інструментом у руках Бога: вони допомагають повернутися до Нього, зберегти людську гідність. В історії про природну катастрофу, пов'язану із загибеллю єгиптян у водах Червоного моря, концептуальним дескриптором є Божа кара як прояв Божої волі, який репрезентується на основі смислових ознак “величність Бога”, “характер катастрофи”, “покарання”, підкріплених множинними іноконтекстами з книг Псалмів та Неемії Старого Заповіту.

Описувана природна катастрофа з книги Вихід Старого Заповіту (The Holy Bible, 1991) сталася після десяти покарань єгипетських, які, на нашу думку, можна вважати попередженням про майбутню подію.

Господь хотів визволити ізраїльський народ з рабства єгипетського, але цьому заважав фараон. Крім того, за наказом фараона єгиптяни кидали єврейських хлопчиків у воду, за що Господь 
вирішив покарати кривдників водою (Щедровицкий, 2014, с. 376). Господь не повідомляє, як саме станеться катастрофа, але на ії початку зазначає, що фараон буде переслідувати народ Ізраїлю, завдяки чому прославиться Господь (will be honoured upon Pharaoh), а єгиптяни таким чином зрозуміють, що Він є єдиним (may know that I am the LORD): “4. And I will harden Pharaoh's heart, that he shall follow after them; and I will be honoured upon Pharaoh, and upon all his host; that the Egyptians may know that I am the LORD. And they did so" (Ex 14: 4). Для втілення свого задуму Господь обрав праведником Мойсея.

Смислову ознаку “величність Бога" в біблійній історії про перехід народу Ізраїлю через Червоне море актуалізовано стилістично піднесеною лексикою і фразеологією: the children of Israel (сини ізраїльські), salvation of the LORD (спасіння Господа), honour (прославлятися), an high hand (сильна рука), прислівником for ever (назавжди), що підсилюють запевнення Господа в неминучості визволення Ізраїлю. Звернення Господа до свого народу, актуалізоване у висловленні з дієсловом у наказовому способі Fear ye not and see the salvation of the LORD, указує на їх зближення, скорочення дистанції між ними, у той час як засоби політемпоральності have seen (бачити), shall see them again no (більше їх не побачите знову) імплікують передбаченість змін, запевняючи в такий спосіб ізраїльтян, що їх спасіння на противагу від єгиптян відбудеться: "13. And Moses said unto the people, Fear ye not, stand still, and see the salvation of the LORD, which he will shew to you to day: for the Egyptians whom ye have seen to day, ye shall see them again no more for ever" (Ex 14: 13).

Смислова ознака "характер катастрофи" випливає з протиставлення двох лексичних одиниць - light (світло) і darkness (темрява). Стоячи в хмарі між табором Ізраїлю і табором Єгипту, Янгол Господній освітлював дорогу ізраїльтянам, тоді як Єгипет був у пітьмі: “19. And the angel of God, which went before the camp of Israel, removed and went behind them; and the pillar of the cloud went from before their face, and stood behind them: 20. And it came between the camp of the Egyptians and the camp of Israel; and it was a cloud and darkness to them, but it gave light by night to these: so that the one came not near the other all the night” (Ex 14: 19-20). У цьому контексті представлено два різних сценарії опису катастрофи. Перший сценарій зосереджено на допомозі ізраїльському народу, другий - на знищенні єгиптян. Поведінка людей під час переходу через море розкривається завдяки використанню дієслів руху: ізраїльтяни спокійно увійшли в море (went into the midst of the sea) та йшли суходолом (walked upon dry land in the midst of the sea), оскільки море розділилося навпіл (the waters were divided), у той час як єгиптяни перебували в хаосі й напрузі: вони були стривожені (troubled), спочатку переслідували ізраїльтян (pursued), а потім почали рятуватися втечею від них (flee), оскільки зрозуміли, що ізраїльський народ захищає Господь.

Наведені сценарії вказують на амбівалентний характер цієї природної катастрофи, оскільки, освітлюючи і вказуючи шлях Ізраїлю, Господь дарував ізраїльському народу життя, а створюючи темряву, перегороджуючи шлях єгиптянам, карав їх смертю. Таким чином, у цій біблійній нарації наявна подвійність оцінки - позитивної, спрямованої на народ ізраїльський, і негативної, що стосується єгиптян.

Хоча єгиптяни переслідували народ Ізраїлю, за волею Бога ізраїльтянам удалося перейти море. Множинні іноконтексти з книг Старого Заповіту, що підтверджують перехід народу Ізраїлю через Червоне море, незважаючи на природну катастрофу, знаходимо в книзі Псалмів: "9. He rebuked the Red sea also, and it was dried up: so he led them through the depths, as through the wilderness. 10. And he saved them from the hand of him that hated them, and redeemed them from the hand of the enemy. 11. And the waters covered their enemies: there was not one of them left" (Ps 106: 9-11), та в книзі Неемії - "11. And thou didst divide the sea before them, so that they went through the midst of the sea on the dry land; and their persecutors thou threwest into the deeps, as a stone into the mighty waters" (Neh 9: 11). Ключовими в цих множинних контекстах є лексичні 
одиниці і вирази, пов'язані семантикою допомоги і покарання, а саме saved, redeemed (урятував), divide the sea (море розійшлося), the waters covered their enemies (води покрили іх ворогів), not left (не залишився), threwest into the deeps (кидати в глибину). Саме вони окреслюють "розповідь величної картини ходи народу Божого по сухому дну між двох стін води, що розступилася. Жезл Мойсея, посланця Яхве, немовби володарює над стихіями, відкриваючи шлях до свободи" (Мень, 2003, с. 204).

Смисловою ознакою "покарання" позначені наслідки катастрофи. Для єгиптян це Божа кара, для ізраїльтян - віра в Господа і Його могутність: "31. And Israel saw that great work which the LORD did upon the Egyptians: and the people feared the LORD, and believed the LORD, and his servant Moses" (Еx 14: 31), що вербалізується лексичними одиницями feared (боялися), believed (повірили).

Смислова структура біблійної історії про перехід народу Ізраїлю через Червоне море вибудовується за певними етапами: 1) пояснюється зміст катастрофи; 2) висвітлюється божественний замисел, що буде досягнутий за посередництва майбутньої катастрофи; 3) обирається праведник, який є спостерігачем і учасником катастрофи; 4) описуються етапи та вияви зазначеної катастрофи; 5) обговорюються ії наслідки (рис. 1).

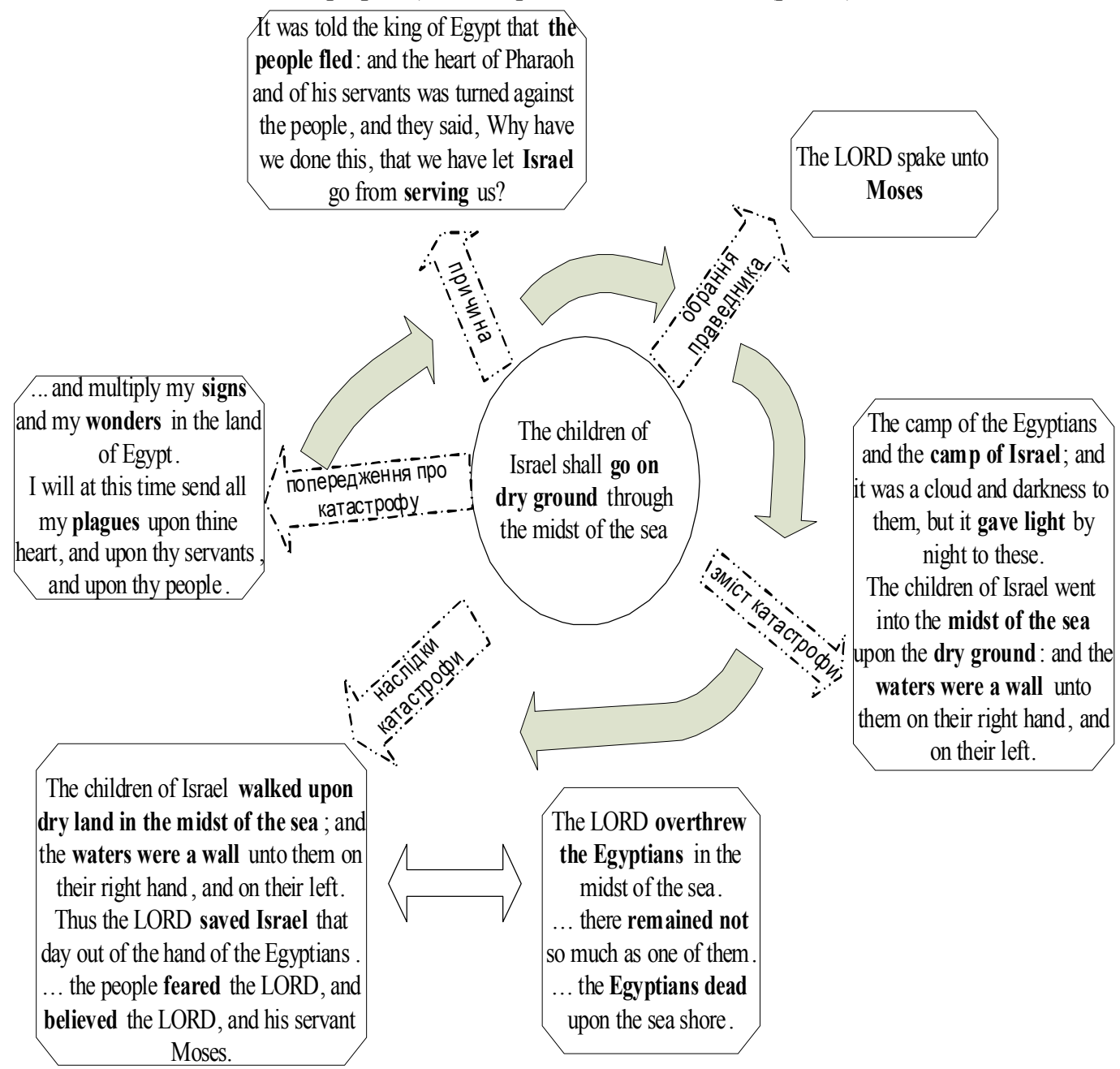

Рис. 1. Смислова структура історії про перехід народу Ізраїлю через Червоне море 
На початку катастрофи Господь попереджає про неминучість майбутньої катастрофи і її причину, а для цього обирає праведника. Катастрофа розгортається за протилежними сценаріями залежно від вектора дії природних явищ. Для ізраїльтян море розступилося, вони пройшли суходолом посередині моря i, таким чином, врятувалися від переслідування єгиптян. I, навпаки, єгиптяни опинилися всередині моря за наказом Господа. Відповідно до змісту катастрофи споглядаємо різні їі наслідки. Єгиптяни загинули, а ізраїльтяни врятувалися й увірували в Господа.

Висновки й перспективи подальших досліджень. Аналіз концептуального простору екодискурсу англомовної Біблії дозволив дійти висновків щодо специфіки ключових дискурсотвірних біблійних екоконцептів БОГ, ПРИРОДА, ЛЮДИНА, СОЦІУМ, які у своєму взаємозв'язку формують концептуальні екотеми Біблії, тобто ті теми, які розкривають сутність закладеного Богом гармонійного існування людини у створеному Ним світі. У нашому дослідженні було визначено такі екотеми: “Створення Богом природи”, “Створення Богом людини (соціуму)”, “Ставлення людини до природи, створеної Богом”, “Приписане Богом ставлення людини до сім’ї і суспільства”, “Ставлення Бога до людини”, “Ставлення людини до Бога”, які розкривають екологічний зміст Біблії. У межах концептуальної екотеми “Ставлення Бога до людини” в історії про перехід народу Ізраїлю через Червоне море ключові дискурсотвірні біблійні екоконцепти БОГ, ЛЮДИНА осмислюються крізь призму екологічного субконцепту ПОКАРАННЯ, репрезентованого концептуальним дескриптором Божа кара як прояв Божої волі, який визначається набором виокремлених смислових ознак у множинних іноконтекстах, які сукупно репрезентують смислову структуру біблійної історії.

Перспективу подальшого дослідження біблійних екотем убачаємо в розкритті когнітивних механізмів формування екоконцептів як ментальних репрезентацій цінностей, утілених у біблійному екодискурсі.

\section{ЛIТЕРАТУРА}

Вежбицкая, А. (1999). Семантические универсалии и описание языков. Москва: Языки русской культуры.

Воробйова, О. П. (2011). Концептологія в Україні: здобутки, проблеми, прорахунки. Вісник Київського національного лінгвістичного університету. Серія Філологія. 14(2), 53-64.

Жаботинская, С. А. (2005). Лексическое значение: принципы построения концептуальной сети. Zlovo z perspektywy jezykoznawcy i tlumacza, tom II. Gdansk: Widawnictwo Uniwersytetu Gdanskiego, 53-62. Взято 3 uaclip.at.ua/2005-Gdanskleksznachenie.doc

Жаботинская, С. А. (2008). Модели репрезентации знаний в контексте различных школ когнитивной лингвистики: интегративный подход. Когнитивные исследования языка. Tuпы знаний и проблемы их классификации. (III). (61-74). Москва-Тамбов.

Жаботинская, С. А. (2013). Имя как текст: концептуальная сеть лексического значения (анализ имени эмоции). Когниция, коммуникация, дискурс. 6, 47-76. Взято з https://sites.google.com/site/ cognitiondiscourse/vypusk-no6-2013/zabotinskaa-s-a

Кагановська, О. М. (2003). Текстові конщепти художньої прози: когнітивна та комунікативна динаміка (на матеріалі франиузької романістики середини ХХ сторіччя). (Автореф. дис. докт. філол. наук). Київ.

Колесов, В. В. (2002). Философия русского слова. Санкт-Петербург: Юна.

Лагутина, А. А. (2013). Доминантные экологические реалии в современном немецком газетнопублицистическом дискурсе и средства их языковой категоризащии. (Автореф. дисс. канд. филол. наук). Воронеж.

Лакофф, Дж., Джонсон, М. (1990). Метафоры, которыми мы живем. Теория метафоры. (с. 387-415). Москва. 
Лэнекер, Р. В. (2006). Концептуальная семантика и символическая грамматика. Bonpocbl когнитивной лингвистики. 3(009), 15-27.

Мартинюк, А. П. (2012). Словник основних термінів когнітивно-дискурсивної лінгвістики. Харків: ХНУ імені В.Н. Каразіна.

Мень, А., протоиерей. (2003). Исагогика. Москва: Фонд имени Александра Меня.

Ніконова, В. Г. (2008). Конщептуальний простір трагічного в п'єсах Шекспіра: поетикокогнітивний аналіз. (Дис. докт. філол. наук). Дніпропетровськ.

Панасенко, Н. И. (2010). Фитонимическая лексика в системе романских, германских и славянских языков (опыт ономасиологического и когнитивного анализа). Черкассы: БРАМА-УКРАИНА.

Приходько, А. М. (2008). Концеепти і концептосистеми в когнітивно-дискурсивній парадигмі лінгвістики. Запоріжжя: Прем'єр.

Пылаева, Е. М. (2015). Актуализаџия ключевых концептов текста перевода: эколингвистический подход (на материале романа А.В. Иванова “Географ глобус пропил” и его перевода на франиузский язык). (Дис. канд. филол. наук). Пермь.

Райкен, Л. (2002). Библия как памятник художественной литературьл. Киев - Санкт-Петербург: Центр просветительских программ МАХШ.

Степанов, Ю. С. (2004). Константы: словарь русской культуры. Москва: Академический Проект.

Широков, В. А., Шевченко, Л. Л. (2010). До питання про системну концептографію Святого Письма. Мовознавство. 4-5, 98-105.

Щедровицкий, Д. В. (2014). Введение в Ветхий Завет. Пятикнижие Моисеево. Москва: Теревинф. Взято 3 http://shchedrovitskiy.ru/PDF/978-5-4212-0184-7_Svodn7.pdf

Clausner, T. C., Croft, W. (1999). Domains and image schemas. Cognitive Linguistics. 10(1), 1-31. doi: $10.1515 / \operatorname{cog} 1.1999 .001$

Fauconnier, G., Turner, M. (2002). The Way We Think: Conceptual Blending and the Mind's Hidden Complexities. New York: Basic Books.

Fillmore, Ch. (1968). The case for case. Universals in Linguistic Theory. (p. 1-88). New York.

Goldberg, A. E. (1995). Constructions: A Construction Grammar Approach to Argument Structure. Chicago, London: University of Chicago Press.

Lakoff, G., Johnson, M. (1980). Metaphors We Live By. Chicago: Chicago University Press.

Langacker, R. W. (2008). Cognitive Grammar: A Basic Introduction. New York: Oxford University Press. doi: 10.1093/acprof:oso/9780195331967.001.0001

Rosch, E. (1988). Principles of categorization. Readings in Cognitive Science. (p. 312-322). doi:10.1016/b978-1-4832-1446-7.50028-5

\section{ДЖЕРЕЛО ІЛЮСТРАТИВНОГО МАТЕРІАЛУ}

The Holy Bible. (1991). The Holy Bible: King James Version. New York: Ivy Books.

\section{REFERENCES}

Clausner, T. C., Croft, W. (1999). Domains and image schemas. Cognitive Linguistics. 10(1), 1-31. doi: $10.1515 / \operatorname{cog} 1.1999 .001$

Fauconnier, G., Turner, M. (2002). The Way We Think: Conceptual Blending and the Mind's Hidden Complexities. New York: Basic Books.

Fillmore, Ch. (1968). The case for case. Universals in Linguistic Theory. (p. 1-88). New York.

Goldberg, A. E. (1995). Constructions: A Construction Grammar Approach to Argument Structure. Chicago, London: University of Chicago Press.

Kahanovs'ka, O. M. (2003). Tekstovi kontsepty khudozhn'oi prozy: kohnityvna ta komunikatyvna dynamika (na materiali frantsuz'koi romanistyky seredyny KhKh storichchia). (Avtoref. dys. dokt. filol. nauk). Kyiv. 
Kolesov, V. V. (2002). Filosofija russkogo slova. Sankt-Peterburg: Juna.

Lagutina, A. A. (2013). Dominantnye jekologicheskie realii v sovremennom nemeckom gazetnopublicisticheskom diskurse i sredstva ih jazykovoj kategorizacii. (Avtoref. diss. kand. filol. nauk). Voronezh.

Lakoff, Dzh., Dzhonson, M. (1990). Metafory, kotorymi my zhivem. Teorija metafory. (s. 387-415). Moskva.

Lakoff, G., Johnson, M. (1980). Metaphors We Live By. Chicago: Chicago University Press.

Langacker, R. W. (2008). Cognitive Grammar: A Basic Introduction. New York: Oxford University Press. doi: 10.1093/acprof:oso/9780195331967.001.0001

Ljeneker, R. V. (2006). Konceptual'naja semantika i simvolicheskaja grammatika. Voprosy kognitivnoj lingvistiki. 3(009), 15-27.

Martyniuk, A. P. (2012). Slovnyk osnovnykh terminiv kohnityvno-dyskursyvnoi linhvistyky. Kharkiv: KhNU imeni V.N. Karazina.

Men', A., protoierej. (2003). Isagogika. Moskva: Fond imeni Aleksandra Menja.

Nikonova, V. H. (2008). Kontseptual'nyj prostir trahichnoho v p'iesakh Shekspira: poetyko-kohnityvnyj analiz. (Dys. dokt. filol. nauk). Dnipropetrovs'k.

Panasenko, N. I. (2010). Fitonimicheskaja leksika v sisteme romanskih, germanskih i slavjanskih jazykov (opyt onomasiologicheskogo i kognitivnogo analiza). Cherkassy: BRAMA-UKRAINA.

Prykhod'ko, A. M. (2008). Kontsepty $i$ kontseptosystemy $v$ kohnityvno-dyskursyvnij paradyhmi linhvistyky. Zaporizhzhia: Prem'ier.

Pylaeva, E. M. (2015). Aktualizacija kljuchevyh konceptov teksta perevoda: jekolingvisticheskij podhod (na materiale romana A.V. Ivanova) "Geograf globus propil" i ego perevoda na francuzskij jazyk). (Dis. kand. filol. Nauk). Perm'.

Rajken, L. (2002). Biblija kak pamjatnik hudozhestvennoj literatury. Kiev - Sankt-Peterburg: Centr prosvetitel'skih programm MAHSh.

Rosch, E. (1988). Principles of categorization. Readings in Cognitive Science. (p. 312-322). doi:10.1016/b978-1-4832-1446-7.50028-5

Shhedrovickij, D. V. (2014). Vvedenie v Vethij Zavet. Pjatiknizhie Moiseevo. Moskva: Terevinf. Vziato z http://shchedrovitskiy.ru/PDF/978-5-4212-0184-7_Svodn7.pdf

Shirokov, V. A., Shevchenko, L. L. (2010). Do pitannja pro sistemnu konceptografiju Svjatogo Pis'ma. Movoznavstvo. 4-5, 98-105.

Stepanov, Ju. S. (2004). Konstanty: slovar' russkoj kul'tury. Moskva: Akademicheskij Proekt.

The Holy Bible. (1991). The Holy Bible: King James Version. New York: Ivy Books.

Vezhbickaja, A. (1999). Semanticheskie universalii i opisanie jazykov. Moskva: Jazyki russkoj kul'tury.

Vorobjova, O. P. (2011). Kontseptolohiia v Ukraini: zdobutky, problemy, prorakhunky. Visnyk Kyivs'koho natsional'noho linhvistychnoho universytetu. Seriia Filolohiia. 14(2), 53-64.

Zhabotinskaja, S. A. (2005). Leksicheskoe znachenie: principy postroenija konceptual'noj seti. Zlovo z perspektywy jezykoznawcy i tlumacza, tom II. Gdansk: Widawnictwo Uniwersytetu Gdanskiego, 53-62. Vziato z uaclip.at.ua/2005-Gdanskleksznachenie.doc

Zhabotinskaja, S. A. (2008). Modeli reprezentacii znanij v kontekste razlichnyh shkol kognitivnoj lingvistiki: integrativnyj podhod. Kognitivnye issledovanija jazyka. Tipy znanij i problemy ih klassifikacii. (III). (61-74). Moskva-Tambov.

Zhabotinskaja, S. A. (2013). Imja kak tekst: konceptual'naja set' leksicheskogo znachenija (analiz imeni jemocii). Kognicija, kommunikacija, diskurs. 6, 47-76. Vziato z https://sites.google.com/site/ cognitiondiscourse/vypusk-no6-2013/zabotinskaa-s-a

Дата надходження до редакиії 07.03.2018 p. Ухвалено до друку 27.04.2018 p. 